\title{
HEALTH LITERACY DAN PERILAKU CERDIK PENDERITA HIPERTENSI DIMASA PANDEMI COVID-19
}

\author{
Baiq Ruli Fatmawati', Marthilda Suprayitna², Kurniati Prihatin ${ }^{3}$, Zainal Arifin ${ }^{4}$, \\ Melati Inayati Albayani ${ }^{5}$ \\ 1,2,3,4,5 STIKes Yarsi Mataram \\ mathildasuprayitna@gmail.com
}

\begin{abstract}
ABSTRAK
Pandemi secara global yang disebabkan Coronavirus Disease 2019 (Covid-19) telah mewabah dan menyebar dengan cepat, dan terjadi secara bersamaan di seluruh dunia. Peningkatan angka kesakitan dan kematian akibat Covid-19 disebabkan oleh adanya penyakit penyerta (comorbid). Hipertensi merupakan salah satu comorbid paling banyak ditemukan pada Covid-19 sehingga penderita hipertensi diharapkan mampu memodifikasi gaya hidup dan mengubah perilaku kesehatan dengan mengoptimalkan health literacy dalam pengelolaan kesehatan. Penelitian ini bertujuan untuk mengetahui hubungan health literacy dan perilaku CERDIK penderita hipertensi di masa pandemi Covid-19. Metode penelitian yang digunakan adalah deskriptif analitik dengan Pendekataan Cross Sectional. Jumlah responden sebanyak 138 orang dengan teknik pengambilan sampel accidental sampling. Data dianalisis dengan chi square dengan hasil penelitian menunjukkan bahwa ada hubungan antara health literacy dengan perilaku CERDIK penderita hipertensi di masa pandemi Covid-19 ( $p$-value: 0,000). Kemampuan penderita hipertensi dalam mencari health literacy yang baik dapat mengubah gaya hidup dan dapat meningkatkan perubahan perilaku CERDIK sehingga derajat kesehatan meningkat secara optimal di masa pandemi Covid-19. Penderita hipertensi diharapkan untuk meningkatkan dan mengembangkan health literacy guna mengoptimalkan derajat kesehatan yang lebih baik di masa pandemi Covid-19.
\end{abstract}

Kata kunci : health literacy, hipertensi, perilaku CERDIK

\section{HEALTH LITERACY AND CERDIK BEHAVIOR ON PATIENTS WITH HYPERTENSION DURING THE COVID-19 PANDEMIC}

\section{ABSTRACT}

Coronavirus Disease-19 (Covid-19) was declared a global pandemic by WHO because it has spread rapidly, coinciding throughout the world. The increase in morbidity and mortality due to Covid-19 was due to comorbid diseases. Hypertension is one of the most common comorbid found on Covid-19, so people with hypertension expect to modify their lifestyle and change their health behavior by optimizing health literacy in health management. This research aimed to determine the correlation between health literacy and CERDIK behavior in patients with hypertension during the Covid-19 pandemic. This research used a descriptive-analytical cross-sectional approach-the research was conducted on 138 respondents. The sampling technique used in this research was accidental sampling. The data were analyzed using chi-square, where the results showed a correlation between health literacy and CERDIK behavior of hypertensive patients during the Covid-19 pandemic (p-value: 0.000). The ability of hypertensive sufferers to seek good health literacy can change their lifestyle. It can also increase CERDIK behavior changes so that their health status increases optimally in patients with hypertension during the Covid-19 pandemic. It hoped that hypertension could improve and develop 
health literacy to optimize a better health status during the Covid-19 epidemic.

Keyword: CERDIK behavior, health literacy, hypertension

\section{PENDAHULUAN}

Masalah kesehatan saat ini masih menjadi fokus perhatian seluruh komponen mulai dari pemerintah pusat sampai ke lapisan masyarakat dan berdampak terhadap seluruh aspek kehidupan adalah Coronavirus Disease 2019 (Covid-19). Sejak ditemukan pertama kali di Wuhan, China pada 31 Desember 2019 Covid-19 dengan cepat telah menyebar ke beberapa negara. Pada awal tahun 2020 penyebaran virus Covid-19 terlapor di 213 negara dengan jumlah kasus positif Covid-19 adalah 2.549.632 kasus, dengan jumlah angka kematian 175. 825 orang karena proses penularannya yang sangat cepat dan mewabah maka pada tanggal 11 Maret 2019 dinyatakan sebagai pandemik global (WHO, 2020).

Indonesia melaporkan pertama kali kejadian Covid-19 berada di daerah Jakarta dengan jumlah kasus sebanyak 2 orang pada tanggal 2 Maret 2020. Setelah itu penularan virus Covid-19 terus meningkat di Indonesia. Satgas Covid-19 melaporkan per 31 Maret 2020 sebanyak 1.528 kasus dengan angka kematian 136 kasus. Tingginya kasus kematian menyebabkan Indonesia menduduki angka mortalitas akibat Covid-19 tertinggi di kawasan Asia Tenggara sebesar $8,9 \%$.

Amerika Serikat menduduki peringkat pertama melebihi China, disusul Spanyol dan Italia yang memiliki tingkat mortalitas paling tinggi di dunia. Covid-19 kian mewabah dan tinggi angka kejadiaanya karena diperparah oleh penyakit bawaan (comorbid) atau pada pasien dengan lansia. Adapun kelompok yang rentan dengan paparan virus Covid-19 adalah hipertensi, Diabetes Melitus (DM), dan penyakit jantung. Oleh karena itu, dibutuhkan perhatian dan penanganan yang sangat serius dari pemerintah pada kelompok komorbid. Hal ini disebabkan oleh jika mereka terpapar virus Covid-19 rentan mengalami perburukan keadaan dan berujung pada meningkatnya risiko kematian (Kemenkes RI, 2020). Komorbid atau penyakit penyerta paling banyak dialami pasien Covid-19 yang meninggal dunia, yaitu hipertensi dan DM (Gunawan et al., 2020).

Upaya pencegahan meluasnya penularan Covid-19 maka perlu dilakukan penguatan penanganan pencegahan penularan Covid-19 pada orang dengan faktor risiko tinggi yang merupakan kelompok rentan Covid-19. Berdasarkan laporan dan informasi data yang telah diberikan, bahwa penyakit tidak menular (hipertensi dan DM) terus mengalami peningkatan kasus tiap tahun dan menjadi perhatian khusus di masa pandemi Covid-19 ini (Kemenkes RI, 2020).

Prevalensi hipertensi secara global masih terus mengalami peningkatan dan merupakan penyakit kronis, namun tidak menular yang ditandai dengan perubahan tekanan darah pada seseorang menjadi lebih tinggi. Menurut Amaral et al., (2015) prevalensi hipertensi terus mengalami peningkatan kejadian, bahkan $25 \%$ dari penduduk dunia mengalami hipertensi menjadi $29 \%$ di tahun 2025. Hipertensi merupakan penyebab utama dari kejadian strok, serangan jantung, dan berbagai penyakit kronik lainnya. Oleh karena itu, hipertensi sering disebut sebagai silent killer dikarenakan gejalanya yang seringkali tidak banyak disadari (Kemenkes, 2019). Gejala yang sering dirasakan oleh penderita hipertensi adalah sakit kepala, nyeri tengkuk, telinga berdenging, pandangan terlihat kabur, vertigo, lemah, dan terkadang disertai mimisan (Kemenkes RI, 2019).

Pengobatan hipertensi dapat dilakukan dengan merubah perilaku dan memodifikasi gaya hidup, disiplin terhadap pantangan dan mengubah 
pola makan dengan membatasi asupan garam tidak lebih dari 6 gram atau dari seperempat sampai setengah sendok teh per harinya, olahraga yang teratur 3-5 kali seminggu seperti jalan, jogging, lari, dan bersepeda selama 20-25 menit, menghindari minuman berkafein dan alkohol, menghindari rokok, dan tidak melupakan minum obat sesuai dengan instruksi tenaga kesehatan agar tekanan darah dapat terkontrol dengan baik (Khanam et al., 2014). Pengendalian stres serta istirahat yang cukup juga penting bagi penderita sebagai bentuk modifikasi gaya hidup (Kemenkes RI, 2019). Program penanggulangan hipertensi oleh pemerintah salah satunya adalah CERDIK. Tujuan dari program kesehatan tersebut yaitu meningkatkan status kesehatan, meningkatnya upaya peningkatan perilaku hidup bersih dan sehat, menurunkan kematian, serta upaya untuk memonitoring dan mendeteksi sedini mungkin terhadap faktor-faktor risiko dari penyakit tidak menular yang terjadi di masyarakat (Drager et al., 2020). Adapun program pemerintah melalui puskesmas adalah adanya perilaku CERDIK untuk masyarakat. Perilaku CERDIK dapat meliputi rutin cek kesehatan, mengenyahkan asap rokok, rajin berolah raga dan aktivitas fisik lainnya, menjaga dan mengatur diet, istirahat yang cukup dan manajemen stres (Kemenkes, 2019).

Hipertensi erat kaitannya dengan perilaku dan pola atau gaya hidup yang kurang baik. Self management behavior pada penderita hipertensi akan terlaksana dengan maksimal jika informasi kesehatan yang diterima baik dan benar. Informasi tentang kesehatan yang diserap oleh setiap orang berbeda-beda tergantung kemampuan seseorang dalam mencari sumber informasi tersebut atau kemampuannya dalam melakukan health literacy (Nurjanah et al., 2016).

Health literacy adalah usaha seseorang dalam mencari sumber informasi kesehatan, kemudian diproses dan dipahami yang hasil akhirnya digunakan dalam memutuskan yang tepat untuk kesehatannya (Jones et al., 2011). Perilaku kesehatan yang baik, biasanya disebabkan oleh health literacy yang baik pula dari seseorang dalam mengupayakan kesehatannya.

Optimalisasi dari health literacy di masa pandemi Covid-19 adalah masyarakat diharapkan lebih aktif dalam manajemen kesehatannya dan dapat mengambil keputusan yang tepat terhadap kesehatannya. Dalam memutuskan apa yang baik dan bermanfaat bagi kesehatan, seseorang membutuhkan sumber informasi yang bisa di peroleh dengan mudah dan dapat dipahami dengan baik berdasarkan latar belakang sosial dan budaya yang ada di masyarakat. Dampak yang sangat besar dari perubahan perilaku seseorang adalah kemampuannya dalam memahami manajemen kesehatan dan menerapkan secara langsung sumber informasi kesehatan yang telah dimiliki (Prihanti et al., 2020).

Berdasarkan fenomena tersebut peneliti merasa penting untuk menggali dan mengoptimalkan hubungan health literacy terhadap perubahan perilaku CERDIK penderita hipertensi di masa pandemi Covid-19 di Desa Mambalan Lombok Barat.

\section{METODOLOGI}

Pada penelitian ini desain yang digunakan adalah deskriptif analitik dengan Pendekatan Cross Sectional. Populasi dalam penelitian ini adalah seluruh pasien hipertensi yang berada di Desa Mambalan Wilayah Kerja Puskesmas Penimbung Lombok Barat. Pengambilan sampel dilakukan dengan accidental sampling diperoleh sampel sebanyak 138 sesuai dengan kriteria inklusi yaitu merupakan seseorang dengan hipertensi primer di Wilayah Kerja Puskesmas Penimbung, Desa Mambalan Lombok Barat, dapat membaca dan menulis, dan bersedia menjadi responden. 
Variabel independen penelitian ini adalah health literacy sedangkan variabel dependen adalah perilaku CERDIK. Pengambilan data dilakukan menggunakan tensimeter dan kuesioner Health Literacy Scale European Union 16 Questions (HLS-EU-Q16) (Bas et al., 2020) dan kuesioner perilaku CERDIK. Kedua kuesioner tersebut dilakukan secara bersamaan pada satu waktu. Teknik pengambilan data dengan cara langsung kunjungan ke rumah responden dengan tetap menggunakan protokol kesehatan dan 3M.

Analisis yang digunakan dalam penelitian ini yaitu menggunakan Uji Statistik Chi-Square untuk mengetahui pengaruh health literacy terhadap perilaku CERDIK pada penderita hipertensi di masa pandemi COVID-19 di: Wilayah Kerja*Puskesmas Penimbung, Desa Mambalan Lombok Barat.

\section{HASIL}

1. Karakteristik Responden

Tabel 1. Karakteristik Responden Meliputi Umur, Jenis Kelamin, Pendidikan, Status Pekerjaan dan Lama Menderita pada Pasien Hipertensi Tahun $2020 \quad(\mathrm{n}=138)$

\begin{tabular}{lcc}
\hline Karakteristik Responden & $\mathbf{n}$ & $\mathbf{\%}$ \\
\hline Umur & & \\
$<40$ & 15 & $10,9 \%$ \\
$40-60$ & 89 & $64,5 \%$ \\
$>60$ & 34 & $24,6 \%$ \\
Jenis Kelamin & & \\
Laki-laki & 60 & $43,5 \%$ \\
Perempuan & 78 & $56,5 \%$ \\
Pendidikan & & \\
SD & 23 & $16,7 \%$ \\
SMP & 46 & $33,3 \%$ \\
SMA & 54 & $39,1 \%$ \\
PT & 15 & $10,9 \%$ \\
Status Pekerjaan & & \\
Bekerja & 53 & $38,4 \%$ \\
Tidak Bekerja & 85 & $61,6 \%$ \\
\hline
\end{tabular}

\begin{tabular}{lrc}
\hline Karakteristik Responden & n & \% \\
\hline Lama Menderita HT & & \\
$\leq 1$ tahun & 27 & $19,6 \%$ \\
$>1$ tahun & 111 & $80,4 \%$ \\
\hline Total & $\mathbf{1 3 8}$ & $\mathbf{1 0 0 \%}$ \\
\hline
\end{tabular}

Karakteristik responden berdasarkan umur didapatkan umur paling dominan berada pada rentang 40-60 tahun (64,5\%), sedangkan jenis kelamin yang paling dominan adalah perempuan sebanyak 78 orang $(56,5 \%)$. Tingkat pendidikan rata-rata adalah lulusan SMA sebanyak 54 orang $(39,1 \%)$, dengan status tidak bekerja sebanyak 85 orang responden (61,6\%). Lama menderita hipertensi rata-rata $>1$ tahun yaitu sebanyak 111 orang $(80,4 \%)$.

Tabel 2. Perilaku Cerdik meliputi Cek Kesehatan Rutin, Enyahkan Asap Rokok, Rajin Berolah Raga, Diet Sehat, Istirahat Cukup, Manajemen Stres pada Pasien Hipertensi Tahun $2020 \quad(n=138)$

\begin{tabular}{lcc}
\hline Variabel & n & \% \\
\hline Cek Kesehatan Rutin & & \\
Baik & 96 & $69,6 \%$ \\
Tidak Baik & 42 & $30,4 \%$ \\
Enyahkah Asap Rokok & & \\
Baik & 79 & $57,2 \%$ \\
Tidak Baik & 59 & $42,8 \%$ \\
Rajin Berolah Raga & & \\
Baik & 90 & $65,2 \%$ \\
Tidak Baik & 48 & $34,8 \%$ \\
Diet Sehat & & \\
Baik & 70 & $50,7 \%$ \\
Tidak Baik & 68 & $49,3 \%$ \\
Istirahat Cukup & & \\
Baik & 112 & $81,2 \%$ \\
Tidak Baik & 26 & $18,8 \%$ \\
Manajemen Stres & & \\
Baik & 75 & $54,3 \%$ \\
Tidak Baik & 63 & $45,7 \%$ \\
\hline Total & $\mathbf{1 3 8}$ & $\mathbf{1 0 0 \%}$ \\
\hline
\end{tabular}


Perilaku CERDIK pada penderita hipertensi menunjukkan bahwa dalam cek kesehatan rutin responden dalam kategori baik sebanyak 96 orang $(69,9 \%)$, dalam mengenyahkan asap rokok kategori baik sebanyak 79 orang $(57,2 \%)$, responden rajin berolah raga sebanyak
90 orang $(65,2 \%)$, diet sehat hipertensi dalam kategori baik sebanyak 70 orang $(50,7 \%)$ dengan istirahat cukup sebanyak 112 orang $(81,2 \%)$, pengelolaan manajemen stres pada pasien hipertensi berada dalam kategori baik sebanyak 75 orang $(65,3 \%)$.

2. Hasil Analisis Penelitian

Tabel 3. Pengaruh Health Literacy Terhadap Perubahan Perilaku CERDIK Penderita Hipertensi Dimasa Pandemi Covid-19 $(n=138)$

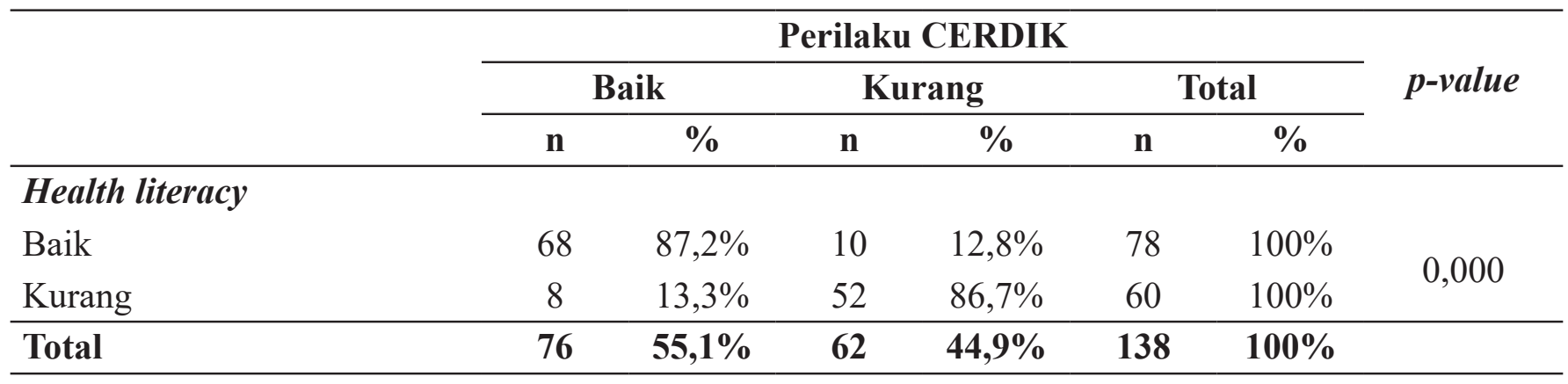

Berdasarkan hasil uji bivariat pada health literacy didapatkan $p$-value $<0,05$ sehingga dapat disimpulkan bahwa health literacy memiliki hubungan yang bermakna terhadap perubahan perilaku CERDIK penderita hipertensi. Pada variabel perilaku CERDIK didapatkan 68 orang $(87,2 \%)$ yang berperilaku baik dalam mengubah gaya hidup penderita hipertensi. Hasil uji statistik didapatkan nilai $p$-value sebesar 0,000 .

\section{PEMBAHASAN}

Karakteristik responden pada penelitian ini menunjukkan bahwa penderita hipertensi rata-rata berusia diantara 40-60 tahun diketahui bahwa semakin bertambahnya usia, prevalensi hipertensi semakin meningkat. Hal ini dikarenakan adanya fisiologis dalam tubuh seperti penebalan dinding arteri akibat adanya penumpukan plak pada lapisan endotel sehingga pembuluh darah mengalami penyempitan dan kaku, yang mengakibatkan terjadinya perubahan tekanan darah menjadi lebih tinggi (Black \& Hawks, 2021).
Jenis kelamin pada penelitian ini menunjukkan bahwa sebagian besar penderita hipertensi berjenis kelamin perempuan. Perempuan di sini adalah perempuan yang mengalami masa menopause yaitu masa terjadinya penurunan hormon estrogen sehingga terjadi peningkatan renin yang memicu terjadinya peningkatan pada tekanan (Kemenkes, 2019).

Tingkat pendidikan sebagian besar responden adalah lulusan SMA. Pendidikan merupakan salah satu faktor yang akan memengaruhi perilaku kesehatan terkait perawatan mandiri penderita hipertensi. Pendidikan adalah pengalaman yang berfungsi untuk mengembangkan kemampuan dan kualitas pribadi seseorang. Semakin tinggi tingkat pendidikan akan semakin besar kemampuannya untuk memanfaatkan pengetahuan dan keterampilannya.

Lama menderita hipertensi rata-rata lebih dari satu tahun. Pengalaman sakit dapat memengaruhi kemampuan seseorang dalam menghadapi masalah yang sama. 
Karakteristik responden berdasarkan perilaku CERDIK pada aspek pasien hipertensi cek rutin kesehatan dalam kategori baik. Hal ini dikarenakan kesadaran para penderita hipertensi akan pentingnya melakukan pemeriksaan kesehatan sebagai upaya promotif dan preventif yang efektif. Selain itu, kesadaran pemeriksaan kesehatan menjadi pilar utama dalam meningkatkan derajat kesehatan karena dampak yang ditimbulkan oleh hipertensi cukup berat sehingga membutuhkan penanganan yang efektif serta deteksi dini yang tepat oleh tenaga kesehatan. Kegiatan skrining hipertensi pada lansia sangat perlu dilakukan baik itu skrining berbasis rumah, puskesmas, dan komunitas untuk menemukan kasus baru serta melakukan manajemen hipertensi dari mulai edukasi, perawatan, dan pengobatanya (Kemenkes RI, 2019). Di masa pandemi Covid-19 penderita hipertensi tidak merasa khawatir dalam memeriksakan kesehatan ke pelayanan kesehatan secara rutin karena mereka telah diberikan penjelasan mengenai protokol kesehatan diri.

Enyahkan asap rokok berada pada kategori baik. Sebagian besar responden tidak merokok dan tidak terpapar asap rokok. Merokok pada dasarnya menghisap carbon monosida (CO) yang memiliki kemampuan mengikat hemoglobin yang ada di dalam sel darah merah sehingga tubuh mengalami kekurangan oksigen dan berusaha untuk memenuhi kebutuhan oksigen dengan cara meningkatkan kompensasi pembuluh darah yang mengakibatkan terjadinya peningkatkan tekanan darah (Kaldara et al., 2015). Di masa pandemi Covid-19 penderita hipertensi tidak terpapar oleh asap rokok. Hal ini dikarenakan berkurangnya perokok aktif di tempat umum, kesadaran mereka menggunakan masker cukup tinggi sehingga dapat mengurangi terpapar asap rokok.

Rutin berolah raga pada responden penderita hipertensi berada pada kategori baik.
Latihan fisik secara rutin (berjalan, bersepeda, berlari atau berenang) dapat menurunkan tekanan darah dan berperan pada penurunan berat badan, dan penurunan stres. Latihan fisik yang teratur mampu mendorong kerja jantung secara optimal sehingga mampu meningkatkan kebutuhan energi sel, jaringan dan organ tubuh. Olah raga rutin minimal 30-60 menit per hari minimal tiga hari per minggu, bisa menurunkan tekanan darah. Di masa pandemi Covid-19 penderita hipertensi tidak mengurangi aktivitas fisik mereka, bahkan sangat aktif melakukan aktivitas fisik dengan berjalan kaki sambil berjemur di bawah matahari pada pukul 09.00 Wita. Hal ini dipercaya dapat meningkatkan imun tubuh dan meningkatkan vitamin D pada kulit.

Diet sehat pada responden penderita hipertensi berada pada kategori baik. Untuk menangani hipertensi fokus pada pembatasan asupan natrium, mempertahankan asupan kalium dan kalsium yang cukup dan mengurangi asupan lemak total dan jenuh (Black \& Hawks, 2021). Di masa pandemi Covid-19 penderita hipertensi lebih selektif dalam memilih menu sehari-hari. Selain berhemat mereka juga lebih memilih memasak sendiri daripada beli masakan yang sudah jadi. Hal ini dikarenakan, penderita hipertensi dapat menakar dalam penggunaan natrium sehari-hari.

Pola istirahat pada responden penderita hipertensi berada pada kategori baik. Hal ini menunjukkan bahwa penderita hipertensi memiliki pola istirahat tidur yang baik. Apabila tidur mengalami gangguan maka tidak terjadi penurunan tekanan darah saat tidur sehingga akan meningkatkan risiko terjadinya hipertensi. Hasil penelitian didukung oleh penelitian (Setiyorini, 2014) bahwa gambaran kualitas tidur lansia hipertensi sebagian besar memiliki kualitas tidur buruk mencapai $(86,7 \%)$ dan tekanan darah pada lansia hipertensi di Gamping Sleman Yogyakarta sebagian besar memiliki hiperensi stage 2 
sebanyak $(46,70 \%)$ didapatkan $p$-value $=0,000$ $(\mathrm{p}<0,05)$.

Manajemen stres pada responden penderita hipertensi berada pada kategori baik. Hal ini menunjukkan bahwa sebagian besar responden penderita hipertensi memiliki manajemen stres yang baik. Stres merupakan reaksi fisiologis dan psikologis yang terjadi pada seseorang. Dalam keadaan stres tubuh melepaskan hormon adrenalin dan kortisol ke dalam darah. Hormon-hormon ini merespon kerja jantung menjadi lebih cepat. Stres yang terus-menerus dapat menyebabkan penyempitan pembuluh darah dan peningkatan kerja jantung, sehingga dapat meningkatkan tekanan darah (Kaldara et al., 2015).

Analisis hubungan health literacy terhadap perilaku CERDIK pada penderita hipertensi di masa pandemi COVID-19 adalah adanya hubungan antara health literacy terhadap perilaku CERDIK pada penderita hipertensi dengan nilai $p$-value $=0,000$.

Hipertensi merupakan salah satu penyakit komorbid pada pasien Covid-19 yang merupakan faktor risiko yang dapat memperburuk Covid-19 (Drager et al., 2020). Angka kejadian Covid-19 di Indonesia terus mengalami peningkatan dengan angka mortalitas yang cukup tinggi di dunia (Handayani et al., 2020). Di masa pandemi Covid-19 ini di masyarakat terjadi kekhawatiran untuk memeriksakan kesehatannya ke pelayanan kesehatan sehingga berbagai macam penyakit tidak dapat dikontrol dengan baik, seperti hipertensi dan DM yang diketahui dapat memberat kondisi seseorang yang terpapar Covid-19. Untuk mencegah hal ini terjadi maka pemerintah membuat program melalui puskesmas yaitu dengan manajemen perilaku CERDIK. Hal ini efektif dan bermanfaat untuk meningkatkan derajat kesehatan (Kemenkes RI, 2019). Pada penelitian ini, didapat kesimpulan bahwa kekhawatiran masyarakat berkurang. Hal ini dikarenakan aktifnya para tenaga kesehatan dalam memberikan promosi kesehatan pada masyarakat. Selain itu, penderita hipertensi juga aktif dalam mencari literasi kesehatan khususnya tentang manajemen hipertensi. Semakin tepat informasi, motivasi dan kemampuan seseoarang dalam mengakses, memahami, dan menggunakan informasi (health Literacy) yang didapatkan maka semakin bijaksana pula seseorang dalam mengambil keputusan (Nurjanah et al., 2016). Mobley et al (2014) mengatakan bahwa health literacy mempunyai peranan penting dalam penanggulangan berbagai masalah kesehatan, dan seseorang yang mempunyai health literacy yang baik cenderung memiliki menajemen diri yang baik agar terhindar dari penyakit kronik (hipertensi). Health literacy mempunyai hubungan dengan penyakit yang dialami oleh seseorang. Selain itu, keyakinan kesehatan dianggap sebagai penentu dari koping yang akan diambil oleh seseorang (Rubin et al., 2013).

\section{SIMPULAN DAN SARAN}

Berdasarkan hasil penelitian dapat disimpulkan bahwa optimalisasi health literacy yang baik dapat meningkatkan perubahan perilaku CERDIK pada penderita hipertensi di masa pandemi Covid-19. Dengan adanya perubahan gaya hidup ke arah yang lebih baik dapat mencegah tingginya tekanan darah pada penderita hipertensi, penyakit komorbid dapat ditekan di masa pandemi Covid-19.

Hasil penelitian ini diharapkan dapat dijadikan pengembangan model health literacy bagi penderita dengan penyakit komorbid untuk meningkatkan derajat kesehatan di masa pandemi Covid-19. Sebagai masukan bagi perawat komunitas bahwa manajemen kesehatan dengan perilaku CERDIK dapat mengoptimalkan kesehatannya di masa pandemi Covid-19. 


\section{DAFTAR PUSTAKA}

Amaral*, O., Chaves, C., Duarte, J., Coutinho, E., Nelas, P., \& Preto, O. (2015). Treatment Adherence in Hypertensive Patients - A Cross-sectional Study. Procedia - Social and Behavioral Sciences, 171(August 2020), 1288-1295. https:// doi.org/10.1016/j.sbspro.2015.01.243

Black, JM, \& Hawks, JH (2021). Keperawatan Medikal Bedah Manajemen Klinis. Edisi 8. Singapura: Elsevier. New York. Elsevier.

Drager, L. F., Pio-Abreu, A., Lopes, R. D., \& Bortolotto, L. A. (2020). Is Hypertension a Real Risk Factor for Poor Prognosis in the COVID-19 Pandemic? Current Hypertension Reports, 22(6), 20-25. https://doi.org/10.1007/s11906-02001057*

Goktas, S., Dagtekin, G., Arslantas, D., \& Unsal, A. (2018).Hls_16.6(1),1-7@.

Gunawan, A., Prahasanti, K., \& Utama, M. R. (2020). Pengaruh Komorbid Hipertensi Terhadap Severitas Pasien Yang Terinfeksi Covid 19. Jurnal Implementa Husada, 1(2), 136. https://doi.org/10.30596/jih. v1i2.4972.

Jones, C. A., Mawani, S., King, K. M., Allu, S. O., Smith, M., Mohan, S., \& Campbell, N. R. C. (2011). Tackling health literacy: Adaptation of public hypertension educational materials for an IndoAsian population in Canada. $B M C$ Public Health, 11(1), 24. https://doi. org/10.1186/1471-2458-11-24

Kaldara, E., Sanoudou, D., Adamopoulos, S., \& Nanas, J. N. (2015). Outpatient management of chronic heart failure. Expert Opinion on Pharmacotherapy, 16(1), 17-41. https://doi.org/10.1517/14 656566.2015 .978286
Kemenkes, R. (2019). Infodantin Stroke Kemenkes Ri 2019. In Infodantin Stroke Kemenkes RI 2019.

Kemenkes RI. (2019). Hipertensi Si Pembunuh Senyap. Kementrian Kesehatan RI, 1-5. https://pusdatin.kemkes.go.id/ resources/download/pusdatin/infodatin/ infodatinhipertensi-si-pembunuh-senyap. pdf.

Khanam, M. A., Lindeboom, W., Koehlmoos, T. L. P., Alam, D. S., Niessen, L., \& Milton, A. H. (2014). Hypertension: adherence to treatment in rural Bangladesh--findings from a population-based study. Global Health Action, 7., 25028. https://doi. org/10.3402/gha.v7.25028.

Mobley, S. C., Thomas, S. D., Sutherland, D. E., Hudgins, J., Ange, B. L., \& Johnson, M. H. (2014). Maternal health literacy progression among rural perinatal women. Maternal and Child Health Journal, 18(8), 1881-1892. https://doi. org/10.1007/s10995-014-1432-0

Nurjanah, Soenaryanti, S., \& Rchmani, E. (2016). Health Literacy Pada Mahasiswa Kesehatan, Sebuah Indikator Kompetensi Kesehatan Yang Penting. VisiKes Jurnal Kesehatan Masyarakat, 15(2), 142. http://publikasi.dinus.ac.id/index.php/ visikes/index $\% 0 \mathrm{AVisiKes}$.

Prihanti, G. S., Sari, N. P., Septiani, N. I., Tobing, L. P. R. L., Adrian, A. R., Ayu, N. R., Abidin, M. Z., \& Farid, H. P. (2020). The Effect Of Counseling On The Adherence Of Therapeutic Hypertension Patients. Jurnal Keperawatan, 11(2), 110-120. https://doi.org/10.22219/jk.v11i2.11943

Rubin, D. L., Freimuth, V. S., Johnson, S. D., Kaley, T., \& Parmer, J. (2013). Training Meals on Wheels Volunteers as Health Literacy Coaches for Older Adults. Health Promotion 
Practice, 15(3), 448-454.. https://doi. org/10.1177/1524839913494786

Setiyorini, Y., Diyah, C., A., K*. (2014). Hubungan kualitas tidur dengan tekanan darah pada lansia hipertensi. Naskah
Publikasi, 12. http://digilib.unisayogya. ac.id.

World Health Organization (WHO). (2020). termasuk penjangkauan dan kampanye, dalam konteks pandemi COVID-19 Panduan interim. 
